Montana Department of Agriculture

Environmental Management Division

Technical Sevices Bureau

Helena, Montana 59620

\title{
A FIELD EVALUATION OF ZINC PHOSPHIDE BAITS FOR CONTROLLING RICHARDSON AND COLUMBIAN GROUND SQUIRRELS
}

by

Monty Sullins and Daniel Sullivan

Vertebrate Pest Specialists

STATE DOCUMENTS COLLECTION

\author{
FEB 211991 \\ MONTANA STATE LIBRARY \\ 1515 E. 6th AVE. \\ HELENA, MONTANA 59620
}

\begin{abstract}
Field trials were conducted to determine the efficacy of zinc phosphide baits on Richardson and Columbian ground squirrels in Montana. The zinc phosphide grain bait formulations tested in May reduced Columbian ground squirrel numbers an average of $47.8 \%$ on prebaited plots and $23.9 \%$ on plots without prebait. In July, average reduction increased to $70.6 \%$ with prebaiting. Richardson ground squirrel activity was reduced $55.7 \%$ and $78.5 \%$, respectively, in spring and summer baitings using zinc phosphide grain baits on plots that were prebaited. Pelleted zinc phosphide baits resulted in an average reduction in Richardson ground squirrel numbers of $32.0 \%$
\end{abstract}




\section{INTRODUCTION}

Richardson (Spermophilus richardsonii) and Columbian (S. columbianus) ground squirrels can cause significant annual economic losses to Montana agriculture. Montana ranchers, farmers, and government agencies need a means of controlling these losses. Strychnine for above-ground uses and sodium monofluoroacetate (Compound1080) were traditionally used to reduce crop and equipment damage caused by field rodents. These uses are no longer available because of recent cancellation of these registrations by the U.S. Environmental Protection Agency. Burrow fumigants and anticoagulant rodenticides used in bait stations may effectively reduce damage on small areas but are not economical or are too labor intensive to use on the large acreages often populated by ground squirrels in Montana. Zinc phosphide, the only currently registered, alternative rodenticide economical to apply on larger acreages, has not proven to be effective on or well accepted by the ground squirrel species in Montana (Sullivan and Sullins 1985; Baril 1980; Swick 1980; Matschke 1979). Some new formulations of zinc phosphide baits have been recently registered in Montana but not field tested under Montana conditions.

\section{OBJECTIVE}

The objective of this study was to test the efficacy of three zinc phosphide formulations during early season and late season baiting periods on Richardson and Columbian ground squirrels.

\section{STUDY AREAS}

The Columbian ground squirrel portion of this study was conducted on pasture and alfalfa fields located in Lewis and Clark County near Helena, Montana, and Flathead County near Kalispell, Montana. The Richardson ground squirrel study plots were located on pasture, alfalfa, or winter wheat fields in Fergus County near Lewistown, Montana, and in Park County near Wilsall, Montana. Vegetation height on the study plots varied from bareground to 4 inches. Daily temperatures ranged from lows of $40^{\circ} \mathrm{F}$ to $60^{\circ} \mathrm{F}$ to highs of $60^{\circ} \mathrm{F}$ to $90^{\circ} \mathrm{F}$, respectively, for the spring and summer baitings.

\section{METHODS}

Three formulations of zinc phosphide bait were tested for efficacy on Richardson and Columbian ground squirrels. Baits tested were: Hopkins $2.0 \%$ zinc phosphide bait on hulled, rolled oats; Hopkins $2.0 \%$ zinc phosphide pellets; and D \& H Formula Rodent Rid-R, a $2.0 \%$ zinc phosphide formulated on hulled, rolled, partially cooked oats.

The test baits were applied in April and July to compare acceptance during early and late squirrel activity seasons. The bait was applied to a total of 17 test plots. Five additional plots were used as nontreatment controls to monitor squirrel activity. 
Columbian plot 2 was prebaited with nontoxic oats twice, 2 days apart. Columbian plots 6 and 7 received no prebait. All other Columbian and Richardson plots were prebaited once with nontoxic oats, 2 days prior to bait application. All baits were applied by hand, using calibrated dippers, at the rate of one teaspoon $(5 \mathrm{~g})$ of bait scattered on bare ground near each burrow.

Efficacy was determined by counting active ground squirrels pretreatment and posttreatment. Visual counts using binoculars were obtained on marked counting areas within treated and control plots. Three counts were made at five minute intervals on each plot for three consecutive days two days before and after treatment. The highest three counts were averaged to provide pretreatment and posttreatment activity indices (AI) for each plot. Percent reduction in activity caused by baiting was computed as follows:

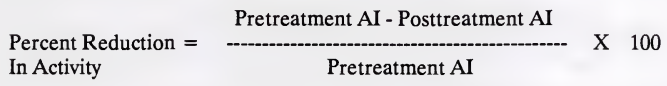

All treated sites were observed for ground squirrel and nontarget mortalities

\section{RESULTS}

No nontarget mortalities were observed on any study plot during the study period.

The efficacy results for the zinc phosphide baits and baiting regimens used of this study are summarized in Tables 1 and 2.

\section{Pelleted Bait}

Reduction in ground squirrel activity on Richardson plots $1,6,7$, and 9 (Table 2) baited with zinc phosphide pellets varied from $11.8 \%$ to $52.7 \%$ and averaged $32 \%$.

\section{Oat Bait - Spring}

Prebaited Richardson ground squirrel plots baited in the spring with zinc phosphide oats (plots $2,3,4$,and 8 , Table 2) averaged $55.7 \%$ (range: $42.3 \%$ to $75 \%$ ) reduction in activity.

Columbian ground squirrel plots that were baited with zinc phosphide in the spring (plots $4,5,6$ and 7 , Table 1) resulted in an average reduction in activity of $47.8 \%$ (range: $43.8 \%$ to $51.8 \%$ ) and $23.9 \%$ (range: $13.0 \%$ to $34.7 \%$ ), respectively, with and without prebaiting. One Columbian plot with sparse vegetation (plot 2, Table 1) was prebaited twice prior to bait application and yielded a $86.9 \%$ reduction in activity. 


\section{TABLE 1. PERCENT CHANGE IN COLUMBIAN GROUND SQUIRREL ACTIVITY WITH $2.0 \%$ ZINC PHOSPHIDE GRAIN BAIT (APRIL, MAY, JULY 1990).}

$\begin{array}{llllcc} & \text { ZINC } & \text { APPLIC. } & \text { VEGET. } & \% & \text { AVE. } \% \\ \text { PLOT } & \text { BAIT } & \text { DATE } & \text { TYPE } & \text { CHANGE } & \text { CHANGE }\end{array}$

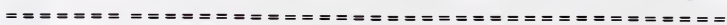

$\begin{array}{lccccc}1^{\mathrm{a}} & \text { Control } & - & \text { Pasture } & -2.8 \\ 2^{\mathrm{a}} & \text { Oats }^{\mathrm{d}, \mathrm{f}} & 4 / 25 / 90 & \text { Pasture } & -86.9 & -86.9\end{array}$

$3^{b}$

Control

Alfalfa

$-2.3$

$4^{b}$

Oats ${ }^{\mathrm{c}}$

$5 / 3 / 90$

Alfalfa

$-43.8$

$5^{b}$

Oats ${ }^{\mathrm{c}}$

$5 / 3 / 90$

Pasture

$-47.8$

$6^{b}$

Oats $^{\mathrm{c}, \mathrm{e}}$

$5 / 4 / 90$

Pasture

$-23.9$

$7^{b}$

Oats ${ }^{\mathrm{c}, \mathrm{e}}$

$5 / 4 / 90$

Pasture

$-34.7$

$8^{b}$

Control

Pasture

$-6.7$

$9^{b}$

Oats ${ }^{\mathrm{c}}$

$7 / 12 / 90$

Pasture

$-78.3$

$10^{b}$

Oats $^{c}$

$7 / 12 / 90$

Alfalfa

a - Lewis and Clark County, Montana.

b - Flathead County, Montana.

c - D \& H Formula Rodent Rid-R, 2.0\% zinc phosphide on hulled, rolled oats.

$\mathrm{d}$ - Hopkins Chemical Co., $2.0 \%$ zinc phosphide on hulled, rolled oats.

e - No prebait applied.

f - Two prebait applications. 

TABLE 2. PERCENT CHANGE IN RICHARDSON GROUND SQUIRREL
ACTIVITY WITH $2.0 \%$ ZINC PHOSPHIDE BAITS (MARCH AND JULY, 1990)

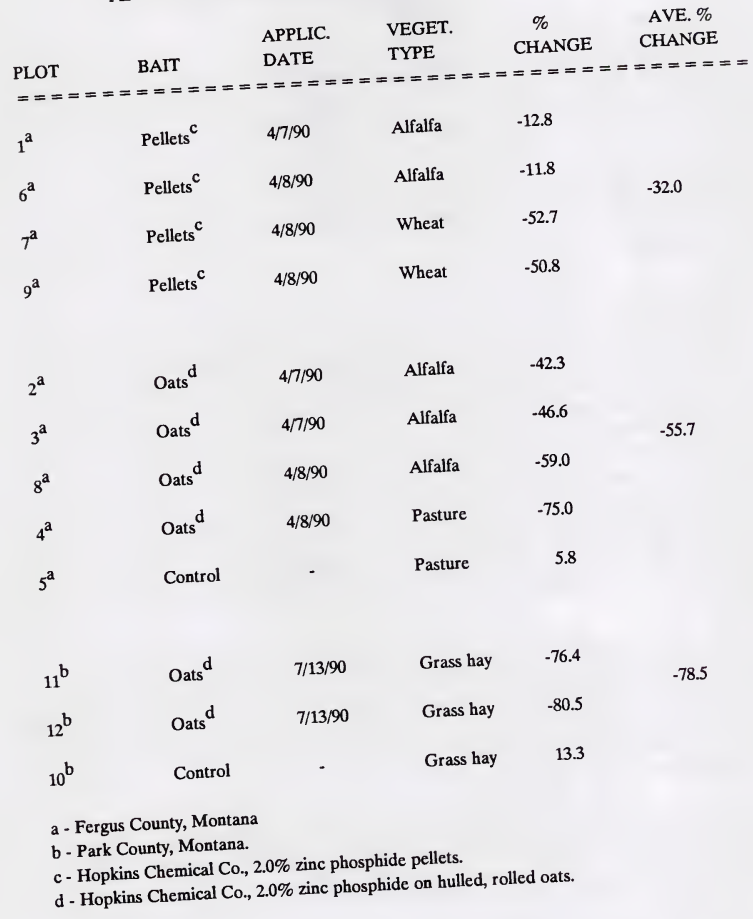


during the spring baiting period. Considerable amounts of zinc phosphide were still present after posttreatment activity counts were conducted.

\section{Qat Bait-Summer}

Prebaited plots treated in the summer with zinc phosphide oats averaged $78.5 \%$ (range: $76.4 \%$ to $80.5 \%$ ) reduction in activity for Richardson ground squirrels (plots 11 and 12 , Table 2 ) and $70.6 \%$ (range: $62.9 \%$ to $78.3 \%$ ) reduction in activity for
Columbian ground squirrels (plots 9 and 10 , Table 1 ).

Prebait was completely consumed prior to bait application. Considerable amounts of zinc phosphide bait was still present at the end of the study.

\section{DISCUSSION}

The pelleted zinc phosphide formulation tested in this study proved least effective in viorage percent reduction of ground squirrel activity. These results agree with previous Montana studies (Sullivan and Sullins 1985; Baril 1980) that have shown pelseeds comprise the majority of by ground squirrels. Since green vegetation and not to be preferred in field conditions where alterrel species' diets, pellets appear Pelleted bait did appear to be more effective alterative food sources are available. $50.8 \%$ reduction) compared to the alfalfa plots (12. wheat field plots $(52.7 \%$ and wheat plants were small and provided litte for ( $12.8 \%$ and $11.8 \%$ reduction). The where the squirrels had cropped them down. cy and provided the squirrels sufficient forn. The alfalfa plants had broken dormanHowever, efficacy was still below that forage to compete with the test bait. damage. One possible reason for poor pellet acceptance may be in the choice of the type of
material used as prebait. All prebaited plots in this study were prebaited with non-
toxic oats following product label directions. Since the puration toxic oats following product label directions. Since the purpose of prebaiting is to accustom the target species to a new food source, the same material used as the bait

The value of prebaiting zinc phosphide grain baits was demonstrated on the Columbian plots. Those plots receiving no oat prebait (plots 6 and 7) averaged 23.9\% reduction in activity. Columbian plots baited during the same time period with
prebait (Columbian plots 4 and 5) averaged $47.8 \%$ reduction in activity. Although
consumption of the prebait was good and acceptance increased, efficacy wat consumption of the prebait was good and acceptance increased, efficacy was still no sufficient to adequately reduce rodent caused damage. Apparently, there is some adversion exhibited by the ground squirels, perhaps odor or taste, to the zinc phos-
phide. 
A comparison of efficacy with and without prebaiting was not made for Richardson ground squirrels in this study, but other Montana studies have shown increased acceptance of zinc phosphide baits after prebaiting (Swick 1980; Sullins 1979a,b).

One of the Columbian plots (plot 2) was prebaited twice prior to bait application and resulted in $86.9 \%$ reduction in activity. However, very sparse vegetation which limited alternate food sources was likely an important factor in obtaining good efficacy on this plot.

Prebaiting twice would triple the labor required in an operational rodent control program and may not be practical or acceptable by applicators when baiting large acreages. Further study may be needed to determine the economics and effectiveness of multiple prebait applications of zinc phosphide baits.

Richardson ground squirrel control operations conducted after the squirrels emerge from hibernation (February - March) but prior to spring green-up (April - May) has been a common practice in Montana. This usually resulted in good control of Richardsons when strychnine grain baits were used before the cancellation of this use. Further testing may also show this is true for zinc phosphide. Weather conditions prevented testing of zinc phosphide baits on the Richardson during this time period. Early baiting prior to green-up is usually not possible for the Columbian ground squirrel. The Columbian commonly emerges from hiberation when green vegetation is already present and their acceptance of grain baits is generally poor at this time. This has restricted effective baiting operations for Columbians to the summer period between juvenile emergence and estivation.

Efficacy of the test baits on both species increased in the summer trials compared to the spring baitings. The increased availability of seeds and grain likely increases the prevalence of these items in the diet of both species. This likely increases the acceptance of grain baits in general, resulting in greater efficacy.

In summary, all zinc phosphide grain and pellet formulations tested in this study, with the exception of that used on the multiple prebaited plot, produced control levels below that generally obtained with rodenticides such as strychnine and Compound 1080. On average, the test baits and baiting regimens used did not result in reduction of squirrel numbers that would provide for long term, economical relief of crop and equipment damage. 


\section{MANAGEMENT RECOMMENDATIONS:}

Zinc phosphide baits are the only presently registered, alternative rodenticide for Richardson and Columbian ground squirrels that can be economically used for large acreage applications. For applicators to obtain the best possible results the following recommendations should be considered:

1. Use zinc phosphide baits formulated on oats. Use of pelleted baits or other carriers is likely to give poor efficacy.

2. Test for bait acceptance prior to application. Delay baiting if acceptance of test bait is poor.

3. Prebait treatment area once, more than once if feasible, with nontoxic oats two days before application of the zinc phosphide bait.

4. Apply bait during periods of best bait acceptance. In Montana, this is usually from mid-June through July. When possible, avoid bait application when abundant green vegetation is present.

5. Even under the best conditions, efficacy with zinc phosphide baits may be less than formerly obtained with other rodenticides.

\section{RECOMMENDATIONS FOR FURTHER STUDY:}

1. Conduct zinc phosphide efficacy trials on the Richardson ground squirrel prior to spring green-up to determine efficacy during this time period.

2. Prebait zinc phosphide pelleted baits with nontoxic pellets to determine if efficacy can be increased.

3. Compare the efficacy and cost effectiveness of multiple prebait applications to increase efficacy of zinc phosphide baits.

\section{ACKNOWLEDGMENTS}

We thank landowners Lyle Swandal, Gordon Petrik, James Green, Doug Arntzen, Keith Arntzen, Don Blasdel, Joe Cloud, Art Weaver and George Algard who allowed us the use of their properties for study sites. Hopkins Agricultural Chemical Company and $\mathrm{D}$ and $\mathrm{H}$ Chemical Company provided the rodent bait formulations tested in this study. George Algard, Judee Wargo, Bob Hart, Dale Osgood and staff of the Flathead County Weed and Rodent District provided field assistance. Bill Dopp provided invaluable assistance in plot location in Flathead County. George Algard reviewed this report. 


\section{LITERATURE CITED}

Baril, S.F. 1980. Efficacy of $2 \%$ zinc phosphide applied with and without prebait for control of the Columbian ground squirrel. Montana Department of Agriculture. Helena, Montana. 9 pp.

Matschke, G.H., et. al. 1979. Population control of Richardson's ground squirrels using $2 \%$ zinc phosphide bait. U.S. Fish and Wildlife Service, Denver Wildlife Research Center, Mammal Damage Control. Denver, Colorado. 35 pp.

Sullins, G.L. 1979a. A summary of the acceptance of strychnine and zinc phosphide baits by black-tailed prairie dogs. Montana Department of Livestock. Helena, Montana. 2 pp.

Sullins, G.L. 1979b. Prebaiting as a means of increasing bait acceptance for control of black-tail prairie dogs. Montana Department of Livestock Report. Helena, Montana. $6 \mathrm{pp}$.

Sullivan, D. and Sullins, G.L. 1985. Acceptance of various rodenticide baits under field conditions by Columbian and Richardson ground squirrels. Montana Department of Agriculture. Technical Report 85-05. $11 \mathrm{pp}$.

Swick, C.D. 1980. A field evaluation of zinc phosphide for reducing Richardson ground squirrels. Montana Department of Livestock. Helena, Montana. 11 pp.

\TR9002.dds 
0

:

1 